\title{
The Impact of Technological Innovation and Industrial Structure Upgrading on New Urbanization: An Empirical Analysis Based on Panel Quantile Regression
}

\author{
Lingfang Wei ${ }^{1}$, Haomin Zhang ${ }^{1,2 *}$, Yu Zhang1 \\ ${ }^{1}$ School of Science, Guilin University of Technology, Guilin, China \\ ${ }^{2}$ Guangxi Colleges and Universities Key Laboratory of Applied Statistics, Guilin University of Technology, Guilin, China \\ Email: ${ }^{\star}$ zhanghm@glut.edu.cn
}

How to cite this paper: Wei, L. F., Zhang, H. M., \& Zhang, Y. (2021). The Impact of Technological Innovation and Industrial Structure Upgrading on New Urbanization: An Empirical Analysis Based on Panel Quantile Regression. Modern Economy, 12, 14631485.

https://doi.org/10.4236/me.2021.1210075

Received: September 5, 2021

Accepted: October 25, 2021

Published: October 28, 2021

Copyright $\odot 2021$ by author(s) and Scientific Research Publishing Inc. This work is licensed under the Creative Commons Attribution International License (CC BY 4.0).

http://creativecommons.org/licenses/by/4.0/

\begin{abstract}
For China, new urbanization is the inevitable direction of economic transformation and modernization. Technological innovation and industrial structure upgrading are the main ways to promote new urbanization. It is a meaningful question of how the technological innovation and the upgrading of industrial structure affect the new urbanization. Based on the panel data of 30 provincial administrative units except Tibet in Mainland of China in 2010-2018, the paper builds a panel quantile regression model to explore the intensity of the impact of technological innovation and industrial upgrading on new urbanization. The empirical results show that technological innovation has a significant positive impact on new urbanization, when new urbanization changes from the low quintile to the high quintile, the marginal impact of technological innovation on the new urbanization changes from 0.6744 to 0.5983 . Besides, the marginal impact of industrial structure upgrading on new urbanization changes from 0.1166 to 0.1843 . Industrial upgrading can promote significantly the development of new urbanization in $0.3-0.9$ quantiles, but the effect is not obvious in the $0.1-0.2$ quantiles.
\end{abstract}

\section{Keywords}

Technological Innovation, Industrial Structure Upgrading, New Urbanization, Quantile Regression

\section{Introduction}

The urbanization of a country is the process of its rural population transferring 
to the city. With the development of China's economy, the gap between the level of urbanization and that of developed countries is narrowing. In 1978, China's urbanization rate was only $17.92 \%$. By 2019 , about 848.43 million people lived in urban areas. The percentage of permanent urban residents reached $60.06 \%$. This means that urbanization has entered a stage of rapid development. The development of urbanization has absorbed a large number of rural populations to non-agricultural sector employment, which has promoted China's economic growth, and also improved the living standards of urban and rural residents. However, in the process of urbanization development, there are many serious problems (Guan et al., 2018), such as urbanization of population lags behind that of land due to the rapid expansion of urban scale. The social security system is not sound, and the ecological environment is seriously polluted, etc. To solve these problems, China has put forward the concept of new urbanization.

Different from the previous development model, the new urbanization is not simply to expand the scale of the city, but more emphasis on people-oriented. By improving the level of education, public health, social security and employment services, a more equitable social system will be established (Chen et al., 2019). At present, China's economic structure is facing transformation and upgrading. The mode of economic growth needs to take industrial upgrading as the goal, and the direction of economic progress must shift from scale expansion to structural upgrading and change from factor-driven and investment-driven to innovation-driven. Through upgrading the industrial structure, increasing employment opportunities, the transformation of urbanization development mode will be promoted and the sustainable development of urban and rural areas will be realized. At the same time, technological innovation can promote the upgrading of industrial structure and improve productivity. As the most active factor of productivity, science and technology play an increasingly important role in promoting social development. Therefore, it is worth to study how scientific and technological innovation and industrial upgrading impact the development of new urbanization.

Based on the above introduction, this paper aims to investigate the impact of technological innovation and industrial structure upgrading on new urbanization in the 30 provincial administrative units except Tibet in Mainland of China from 2010 to 2018. The main contributions of this study are as follows: 1) It systematically analyzes the influence mechanism of technological innovation and industrial structure upgrading on the new urbanization, which provides a clearer perspective for the study of new urbanization. 2) Most previous studies ignore the heterogeneity of the impact of technological innovation and industrial structure upgrading on new urbanization, which will lead to deviation in the conclusion. To overcome this shortcoming, panel quantile regression method is used to explore the potential heterogeneity. 3) The existing literature usually uses a single indicator to measure the new urbanization. Although some scholars have used multiple indicators such as demographic, economic, and social for comprehensive measurement, few studies take into account the ecological environ- 
ment and urban-rural integration. In addition, this study also has some limitations: a) There are some limitations in the selection of indicators. Technological innovation is a complex system, involving multiple indicators, and a large amount of data cannot be available. We only selected several representative indicators, but does not fully consider the whole process of scientific and technological innovation, which may affect the empirical results. b) This study only examines the relationship between technological innovation and new urbanization, industrial structure and new urbanization, without considering the interactive relationship among the three. Therefore, intermediary effects can be added for further analysis to make the research results more comprehensive and complete.

The rest of this paper is organized as follows: Section 2 provides a review of the literature. Section 3 describes the data sources and analysis methods. Section 4 presents the empirical research results. Section 5 contains the conclusions and suggestions.

\section{Literature View}

\subsection{The Impact of Industrial Structure Upgrading on New Urbanization}

Regarding the impact of industrial structure upgrading on new urbanization, some scholars believe that industrial structure upgrading can promote the development of new urbanization. (Bertinelli \& Strobl, 2007) studied the relationship between industry and urbanization, and pointed out that urbanization is closely linked to secondary and tertiary industries, which have promoted the growth of the provincial economy and the upgrading of industrial structure. Meanwhile, industrial upgrading also promotes urban development through labor transfer. (Davis \& Henderson, 2003) discussed the interaction between industrial structure and urbanization, and thought that primary industry cannot always be the leading industry of a country or region. In the future, the secondary or tertiary industry will play a principal role. In the process of industrial transformation, the labor force shifted from rural areas to cities, which promoted the development of cities, which promoted the development of cities. (Murakami, 2015) concluded that in the period of rapid economic growth in Japan, industrialization attracted a large number of migrants, which promoted the process of urbanization. (Wang et al., 2021) based on the panel data of China from 2003 to 2017, a vector autoregressive model and a panel threshold model were established. It is noted that modern urbanization and industrial upgrading have mutually promoting effects, and urbanization has a greater role in promoting the upgrading of industrial structure. (Song \& Zhu, 2020) studied the spatial-temporal pattern and driving forces of urbanization in China's border areas, and found that transportation and industry are important driving forces of urbanization in border areas. (Gan et al., 2020) based on the empirical analysis of 18 cities in Sichuan Province, it is found that the integration of urban and rural industries is the key factor influencing the development of urbanization. (Zou et 
al., 2016) combined urbanization the three industries, and a P-VAR model was built. It found that the urbanization and service industry have a two-way integration effect.

\subsection{The Impact of Technological Innovation on New Urbanization}

With the development of urbanization, the literature has extensively studied the impact of technological innovation on urbanization. Using cross-country panel data from 1960 to 1990, (Carlino et al., 2007) confirmed that there is a close relationship among the urbanization, patent intensity and employment density in the United States. A similar conclusion was also proposed by (Trip, 2013), who pointed out that technological innovation is one of the important approaches to urban development. The findings of (Andersson et al., 2009) suggested that through guiding the distribution of higher education resources in Sweden, students' creativity and regional productivity were stimulated, which influenced the development of urban areas. The results of (Zhang et al., 2018) believed that technological innovation is an essential driving force for urban economic growth, but science and technology do not always play green attributes. Resulting from the influence of various factors such as urban industrial structure, urban ecology may be improved or destroyed. The empirical investigation by $\mathrm{Wu}$ et al., 2016) affirmed that secondary and tertiary industries and technological progress are the two main factors influencing the urbanization of Baotou City, and the urban expansion was affected by the integration of technology and industry. A recent study by (Li \& Li, 2020) stated that economic development in the Pearl River Delta region has shifted from factor-driven to innovation-driven, and new job opportunities are created by automation and technological progress, which will become a key driving force for China's urbanization. Based on the comprehensive index system of new urbanization and technological innovation, (Shang et al., 2018) established regression analysis to prove that there is a long-term balanced positive relationship between technological innovation and new urbanization in Shaanxi Province. It is argued that the problems left behind by the process of urbanization can be solved by technological innovation.

The existing literature has revealed that the industrial structure upgrading and technological innovation can effectively promote the development of new urbanization, but they usually use a single indicator to measure the new urbanization. Although some scholars use multiple indicators such as population, economy and society for comprehensive measurement, there are few studies take into account the ecological environment and urban-rural integration.

\section{Data Source and Methods}

\subsection{Variable Description and Index Calculation}

1) Explained variable. The explained variable is the comprehensive measure value of new urbanization (urb). Traditional urbanization is usually expressed by population urbanization or land urbanization, while new urbanization focuses 
more on sustainable development, which requires coordinated and green development between urban and rural areas. Based on the summary of the existing literature, this paper constructs an evaluation index system from five dimensions: demographic, economic, social, ecological environment and urban-rural integration, as demonstrated in Table 1.

Since the new urbanization evaluation system contains multi-dimensional indicators, subjective assignment may cause evaluation errors. We adopt a more objective entropy method to measure the variables. The specific steps are as following.

Table 1. The evaluation index system of new urbanization.

\begin{tabular}{|c|c|c|c|c|}
\hline Target layer & Factor layer & Indicator layer & & Weight \\
\hline \multirow{17}{*}{$\begin{array}{l}\text { Level of new } \\
\text { urbanization }\end{array}$} & \multirow{4}{*}{$\begin{array}{l}\text { New urbanization } \\
\text { of the population }\end{array}$} & Urbanization rate of population (\%) & + & 0.062 \\
\hline & & $\begin{array}{l}\text { Urban population density } \\
\text { (Person/square kilometer) }\end{array}$ & + & 0.066 \\
\hline & & $\begin{array}{l}\text { Employment proportion of } \\
\text { secondary and tertiary industries (\%) }\end{array}$ & + & 0.041 \\
\hline & & Unemployment rate in urban (\%) & - & 0.083 \\
\hline & \multirow{3}{*}{$\begin{array}{l}\text { New urbanization } \\
\text { of the economic }\end{array}$} & Per capita GDP (yuan) & + & 0.024 \\
\hline & & $\begin{array}{l}\text { Proportion of output value of } \\
\text { secondary and tertiary industries (\%) }\end{array}$ & + & 0.095 \\
\hline & & $\begin{array}{l}\text { Average wage of employees in } \\
\text { Urban Units (yuan) }\end{array}$ & + & 0.108 \\
\hline & \multirow{4}{*}{$\begin{array}{l}\text { New urbanization } \\
\text { of the social }\end{array}$} & Built-up area (Square kilometers) & + & 0.042 \\
\hline & & Road area per capita (square meter) & + & 0.047 \\
\hline & & $\begin{array}{l}\text { Health professionals per } 1000 \\
\text { people (person) }\end{array}$ & + & 0.163 \\
\hline & & $\begin{array}{l}\text { Number of urban employees } \\
\text { participating in basic endowment } \\
\text { insurance (ten thousand person) }\end{array}$ & + & 0.053 \\
\hline & \multirow{4}{*}{$\begin{array}{l}\text { New urbanization } \\
\text { of the ecological } \\
\text { environment }\end{array}$} & $\begin{array}{l}\text { Park green area per capita } \\
\text { (Square meter) }\end{array}$ & + & 0.023 \\
\hline & & $\begin{array}{l}\text { Green coverage rate of built-up } \\
\text { area }(\%)\end{array}$ & + & 0.019 \\
\hline & & $\begin{array}{l}\text { Harmless treatment rate of } \\
\text { domestic garbage }(\%)\end{array}$ & + & 0.055 \\
\hline & & $\begin{array}{l}\text { Proportion spent on } \\
\text { environmental protection (\%) }\end{array}$ & + & 0.063 \\
\hline & \multirow[b]{2}{*}{$\begin{array}{l}\text { Urban-rural } \\
\text { integration }\end{array}$} & $\begin{array}{l}\text { Income comparison of urban and } \\
\text { rural residents (rural = } 1)\end{array}$ & - & 0.03 \\
\hline & & $\begin{array}{l}\text { Consumption expenditure } \\
\text { comparison of urban and rural } \\
\text { residents (rural =1) }\end{array}$ & - & 0.025 \\
\hline
\end{tabular}

Note: "+" indicates that the indicator is a positive indicator, and "-" indicates that the indicator is a negative indicator. 
In the first step, due to the different dimensions of the data, it is necessary to standardize the data before calculating the comprehensive index. In this paper, the range transformation method is used to standardize the index. The specific calculation method for positive indicators is

$$
X_{i j}=\frac{x_{i j}-\min \left(x_{i j}\right)}{\max \left(x_{i j}\right)-\min \left(x_{i j}\right)} .
$$

The specific calculation method for negative indicators is

$$
X_{i j}=\frac{\max \left(x_{i j}\right)-x_{i j}}{\max \left(x_{i j}\right)-\min \left(x_{i j}\right)} .
$$

Here, $x_{i j}$ is the value of the $j$ th indicator of the $i$ th province, $\min \left(x_{i j}\right)$ is the minimum value of the $j$ th indicator in the $i$ th province, and $\max \left(x_{i j}\right)$ is the maximum value of the $t$ th index in the $i$ th province.

The second step is to calculate the proportion of the $i$ th province under the $j$ th index:

$$
P_{i j}=\frac{X_{i j}}{\sum_{i=1}^{n} X_{i j}} .
$$

The third step is to calculate the entropy value of the $t$ th index:

$$
H_{j}=-(\ln n)^{-1} \sum_{i=1}^{n} P_{i j} \ln \left(P_{i j}\right), H_{j} \in[0,1] .
$$

The fourth step is to calculate the information entropy redundancy of the th index:

$$
D_{j}=1-H_{j} .
$$

The fifth step is to calculate the weight of the th index:

$$
W_{j}=\frac{D_{j}}{\sum_{i=1}^{n} D_{j}} .
$$

The sixth step is to calculate the composite measure for each province:

$$
Z_{j}=\sum_{j=1}^{n} W_{j} X_{i j}
$$

According to the entropy method calculation steps, new urbanization comprehensive measurement index in the 30 provinces from 2010 to 2018 can be calculated. The results are shown in Table 2.

As can be seen from Table 2, at the beginning of the examination period, new urbanization was relatively low in every region, with most provinces in the 0.1 0.2 range. There were eight region's composite index higher than 0.3 namely Beijing, Tianjin, Liaoning, Shanghai, Jiangsu, Zhejiang, Shandong, and Guangdong. In 2018, the new urbanization level of the various provinces has improved, among which Beijing and Guangdong have reached more than 0.6, and other 
L. F. Wei et al.

Table 2. The new urbanization comprehensive index in the 30 provinces from 2010 to 2018.

\begin{tabular}{|c|c|c|c|c|c|c|c|c|c|}
\hline Year & 2010 & 2011 & 2012 & 2013 & 2014 & 2015 & 2016 & 2017 & 2018 \\
\hline Beijing & 0.451 & 0.479 & 0.488 & 0.537 & 0.554 & 0.566 & 0.587 & 0.618 & 0.637 \\
\hline Tianjin & 0.341 & 0.37 & 0.384 & 0.412 & 0.416 & 0.433 & 0.446 & 0.487 & 0.455 \\
\hline Hubei & 0.279 & 0.289 & 0.306 & 0.327 & 0.349 & 0.374 & 0.381 & 0.412 & 0.439 \\
\hline Shanxi & 0.25 & 0.266 & 0.284 & 0.31 & 0.321 & 0.325 & 0.34 & 0.353 & 0.375 \\
\hline Inner Mongolia & 0.243 & 0.267 & 0.298 & 0.32 & 0.355 & 0.374 & 0.383 & 0.384 & 0.39 \\
\hline Liaoning & 0.301 & 0.315 & 0.333 & 0.356 & 0.365 & 0.376 & 0.35 & 0.377 & 0.379 \\
\hline Jilin & 0.228 & 0.264 & 0.281 & 0.302 & 0.328 & 0.333 & 0.332 & 0.329 & 0.342 \\
\hline Heilongjiang & 0.284 & 0.3 & 0.307 & 0.317 & 0.319 & 0.341 & 0.34 & 0.365 & 0.371 \\
\hline Shanghai & 0.365 & 0.403 & 0.41 & 0.426 & 0.429 & 0.443 & 0.462 & 0.494 & 0.526 \\
\hline Jiangsu & 0.416 & 0.441 & 0.464 & 0.493 & 0.513 & 0.536 & 0.553 & 0.575 & 0.593 \\
\hline Zhejiang & 0.378 & 0.399 & 0.42 & 0.446 & 0.468 & 0.482 & 0.494 & 0.52 & 0.542 \\
\hline Anhui & 0.226 & 0.256 & 0.275 & 0.298 & 0.323 & 0.34 & 0.354 & 0.388 & 0.421 \\
\hline Fujian & 0.265 & 0.287 & 0.312 & 0.332 & 0.352 & 0.369 & 0.387 & 0.41 & 0.447 \\
\hline Jiangxi & 0.281 & 0.298 & 0.321 & 0.327 & 0.335 & 0.351 & 0.373 & 0.396 & 0.415 \\
\hline Shandong & 0.366 & 0.388 & 0.418 & 0.453 & 0.465 & 0.485 & 0.501 & 0.52 & 0.529 \\
\hline Henan & 0.265 & 0.279 & 0.303 & 0.316 & 0.342 & 0.364 & 0.388 & 0.418 & 0.452 \\
\hline Hubei & 0.24 & 0.256 & 0.279 & 0.308 & 0.334 & 0.359 & 0.376 & 0.394 & 0.434 \\
\hline Hunan & 0.222 & 0.232 & 0.253 & 0.27 & 0.292 & 0.307 & 0.325 & 0.344 & 0.371 \\
\hline Guangdong & 0.476 & 0.514 & 0.541 & 0.572 & 0.603 & 0.629 & 0.655 & 0.674 & 0.695 \\
\hline Guangxi & 0.166 & 0.186 & 0.203 & 0.217 & 0.248 & 0.273 & 0.287 & 0.315 & 0.338 \\
\hline Hainan & 0.206 & 0.271 & 0.263 & 0.276 & 0.289 & 0.295 & 0.305 & 0.318 & 0.342 \\
\hline Chongqing & 0.231 & 0.279 & 0.309 & 0.316 & 0.328 & 0.346 & 0.359 & 0.383 & 0.417 \\
\hline Sichuan & 0.231 & 0.252 & 0.28 & 0.299 & 0.319 & 0.322 & 0.356 & 0.384 & 0.423 \\
\hline Guizhou & 0.122 & 0.138 & 0.166 & 0.198 & 0.216 & 0.237 & 0.269 & 0.289 & 0.314 \\
\hline Yunnan & 0.166 & 0.183 & 0.2 & 0.188 & 0.225 & 0.236 & 0.27 & 0.291 & 0.309 \\
\hline Shaanxi & 0.254 & 0.285 & 0.299 & 0.317 & 0.338 & 0.337 & 0.349 & 0.375 & 0.396 \\
\hline Gansu & 0.163 & 0.184 & 0.204 & 0.227 & 0.249 & 0.266 & 0.28 & 0.304 & 0.31 \\
\hline Qinghai & 0.183 & 0.213 & 0.233 & 0.26 & 0.265 & 0.285 & 0.294 & 0.31 & 0.329 \\
\hline Ningxia & 0.227 & 0.229 & 0.24 & 0.265 & 0.295 & 0.306 & 0.317 & 0.347 & 0.369 \\
\hline Xinjiang & 0.238 & 0.252 & 0.26 & 0.279 & 0.303 & 0.299 & 0.321 & 0.334 & 0.364 \\
\hline
\end{tabular}

provinces have reached above 0.3 . Generally speaking, as time goes by, the new urbanization in each province has shown an increasing trend year by year.

2) Core explanatory variables. The core explanatory variables are technological innovation (tech) and industrial structure upgrading (indus). Technological innovation is a hybrid product of discovery, production, and application. To fully reflect the level of scientific and technological innovation (Kijek \& Kijek, 2010), this paper constructs an evaluation system from four aspects: technological environment, input, output and market application, as showed in Table 3. 
Table 3. The evaluation index system of technological innovation.

\begin{tabular}{|c|c|c|c|c|}
\hline Target layer & Factor layer & Indicator layer & & Weight \\
\hline \multirow{10}{*}{$\begin{array}{l}\text { Level of } \\
\text { technological } \\
\text { innovation }\end{array}$} & \multirow{2}{*}{$\begin{array}{l}\text { Technological } \\
\text { innovation } \\
\text { environment }\end{array}$} & $\begin{array}{l}\text { Proportion of technology expenditure } \\
\text { in local fiscal expenditure (\%) }\end{array}$ & + & 0.074 \\
\hline & & $\begin{array}{l}\text { Average number of college students } \\
\text { per } 100,000 \text { population (person) }\end{array}$ & + & 0.034 \\
\hline & \multirow{4}{*}{$\begin{array}{l}\text { Technological } \\
\text { innovation } \\
\text { investment }\end{array}$} & $\begin{array}{l}\text { Full-time equivalent of } \mathrm{R} \& \mathrm{D} \\
\text { personnel (Person-year)/regional } \\
\text { population }\end{array}$ & + & 0.114 \\
\hline & & $\mathrm{R} \& \mathrm{D}$ input intensity (\%) & + & 0.073 \\
\hline & & $\begin{array}{l}\text { Expenditures for new product } \\
\text { development of enterprises above } \\
\text { designated size (ten thousand } \\
\text { yuan)/regional GDP }\end{array}$ & + & 0.065 \\
\hline & & $\begin{array}{l}\text { Internal expenditure of R\&D funds } \\
\text { in high-tech industry (ten thousand } \\
\text { yuan)/regional GDP }\end{array}$ & + & 0.091 \\
\hline & \multirow{2}{*}{$\begin{array}{l}\text { Technological } \\
\text { innovation output }\end{array}$} & $\begin{array}{l}\text { Valid number of three patents } \\
\text { (pieces)/regional population }\end{array}$ & + & 0.163 \\
\hline & & $\begin{array}{l}\text { Scientific papers published by } \\
\text { colleges and Universities } \\
\text { (pieces)/Number of students }\end{array}$ & + & 0.099 \\
\hline & \multirow{2}{*}{$\begin{array}{l}\text { Technological } \\
\text { innovation } \\
\text { transformation } \\
\text { ability }\end{array}$} & $\begin{array}{l}\text { Technology market turnover (ten } \\
\text { thousand yuan)/regional GDP }\end{array}$ & + & 0.226 \\
\hline & & $\begin{array}{l}\text { Sales revenue of new products of } \\
\text { industrial enterprises above } \\
\text { designated size (ten thousand } \\
\text { yuan)/regional GDP }\end{array}$ & + & 0.06 \\
\hline
\end{tabular}

Note: “+" indicates that the indicator is a positive indicator, and "-" indicates that the indicator is a negative indicator.

According to formulas (1) to (7), the comprehensive measurement value of technological innovation in the 30 provinces from 2010 to 2018 is obtained, and is presented in Table A1. With the growth of years, the ranking of technological innovation among provinces has changed little. In this paper, only the average value of technological innovation indicators from 2010 to 2018 is given, and its spatial distribution is shown in Figure 1.

As can be noted from Figure 1, the highest average technology innovation index ranking is Beijing, which is 0.719 , followed by Shanghai, which is 0.463 . The average measure of technological innovation in Guangdong, Jiangsu, Tianjin and Zhejiang is between $0.2-0.3$. In addition, there are ten regions between 0.1 and 0.2 , and fourteen areas are below 0.1. From the Figure 1, we can know that in developed regions its technological innovation level is quite high, such as Beijing, Shanghai and Guangdong. In underdeveloped areas, the level of technological innovation is also relatively low, such as Hainan, Xinjiang. On the 


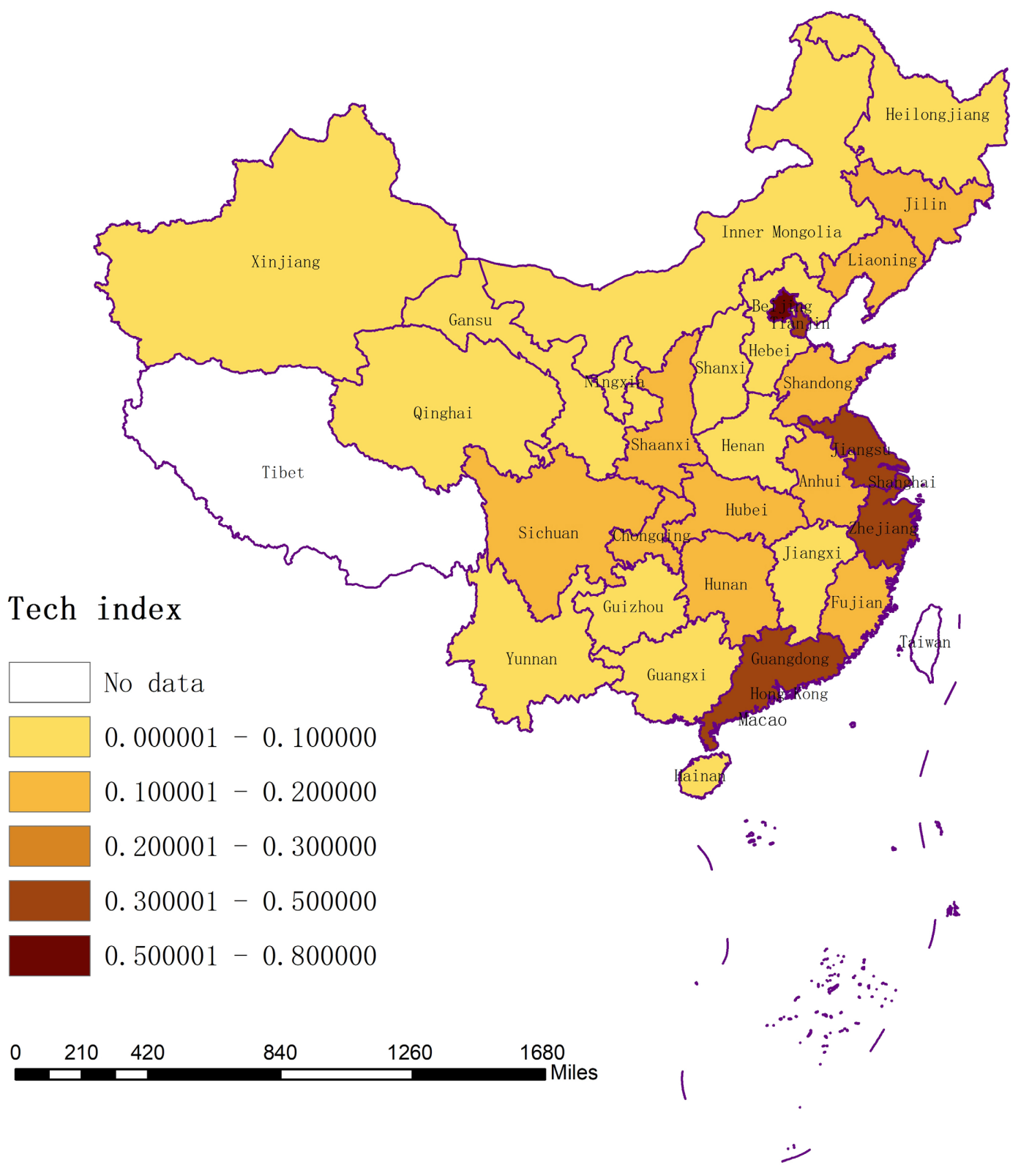

Figure 1. Spatial distribution of the average index of technological innovation in the 30 provinces from 2010 to 2018 .

whole, there are obvious differences in the technological innovation levels among different provinces, and it has noticeable convergence characteristics with regional economic development.

Industrial structure upgrading refers to the adjustment of industrial structure from low-level to high-level forms. It is manifests that the proportion of the primary industrial output value is gradually decreasing, while the proportion of the tertiary industry is rising. Considering that the industrial structure upgrading is not only the change of a single industry, but also a complex process of the three industries common change. Therefore, based on Wang's practice (Yu \& Wang, 2021), industrial structure upgrading coefficient is used to reflect the 
overall upgrading among the three industries, and its expression is

$$
\text { indus }=\sum_{i=1}^{3} q_{i} \times i=q_{1} \times 1+q_{2} \times 2+q_{3} \times 3 \text {. }
$$

Here $q_{i}$ represents the ratio of the added value of the industry $i$ to the total output value. The closer the industrial upgrading coefficient is to 3 , the higher the industrial structure upgrading level is. On the contrary, the smaller the index, the lower the industrial structure.

According to the formula (8), Industrial structure upgrading coefficient in the 30 provinces from 2010 to 2018 can be acquired, it is listed in Table A2. The average values are shown in Table 4. It can be seen that the industrial structure upgrading in Beijing, Shanghai, and Tianjin is relatively high, while in Guangxi and Qinghai is relatively low.

3) Control variables. a) Government welfare fiscal expenditure (gov). Government finance welfare expenditures play an important role in the development of urbanization. To promote urbanization, it is necessary for the government to improve a series of residents' welfare such as social welfare, medical and health care, and education. And ensure that migrant workers can equally enjoy basic public services and social welfare. Therefore, government welfare expenditure is represented by the ratio of the total expenditure on education, medical and health, culture, and social security in the fiscal expenditure. b) Human capital stock (hr). The more human capital there is, the better the urbanization development in a region will be. Referring to Lee's method (Lee and Lee, 2016), the

Table 4. The average coefficient of industrial structure upgrading in the 30 provinces.

\begin{tabular}{cccccc}
\hline Province & Level & Rank & Province & Level & Rank \\
\hline Beijing & 2.79 & 1 & Inner Mongolia & 2.34 & 16 \\
Shanghai & 2.66 & 2 & Sichuan & 2.33 & 17 \\
Tianjin & 2.52 & 3 & Hainan & 2.32 & 18 \\
Guangdong & 2.47 & 4 & Heilongjiang & 2.32 & 19 \\
Zhejiang & 2.45 & 5 & Jilin & 2.31 & 20 \\
Shanxi & 2.44 & 6 & Shaanxi & 2.31 & 21 \\
Jiangsu & 2.43 & 7 & Hebei & 2.31 & 22 \\
Chongqing & 2.42 & 8 & Guizhou & 2.31 & 23 \\
Liaoning & 2.38 & 9 & Yunnan & 2.3 & 24 \\
Shandong & 2.38 & 10 & Jiangxi & 2.3 & 25 \\
Ningxia & 2.37 & 11 & Henan & 2.3 & 26 \\
Hunan & 2.36 & 12 & Xinjiang & 2.29 & 27 \\
Gansu & 2.36 & 13 & Anhui & 2.29 & 28 \\
Hubei & 2.35 & 14 & Guangxi & 2.25 & 29 \\
Fujian & 2.34 & 15 & Qinghai & 2.1 & 30 \\
\hline
\end{tabular}


average years of education is used to indicate human capital. The specific formula is as following:

$$
\mathrm{hr}=\frac{\text { primary } \times 6+\text { junior } \times 9+\text { senior } \times 12+\text { college } \times 16}{\text { population }} .
$$

c) Foreign trade is an inexhaustible driving force for good economic operation. Trade opening can promote regional industrial upgrading, increase employment, and indirectly promote the development of new urbanization. In this paper, the ratio of total import and export to GDP is used to represent trade openness. d) Financial development efficiency (fin). Due to the financial funds of local governments are limited, which is difficult to meet the long-term development of new urbanization. Correspondingly, financial investment can provide support for the urbanization development. Referring to Lv's method (Lv et al., 2021), the loan-to-deposit ratio of financial institutions is used to express the financial development efficiency

\subsection{Data Sources}

Our research objects are the 30 provinces in China from 2010 to 2018 (excluding Tibet, Hong Kong, Macao and Taiwan). The raw data are available from the China Statistical Yearbook, China Population and Employment Statistical Yearbook, China Science and Technology Statistical Yearbook. Table 5 reports the descriptive statistics of all variables.

\subsection{Methods}

The classical regression model only describes the average situation, while the quantile regression method can comprehensively describes the effects of different levels. Therefore, based on a panel quantile regression model, this paper examines the impact of technological innovation and industrial upgrading on new urbanization. Quantile regression was first proposed by (Koenker \& Bassett, 1978). Later (Koenker, 2004) combined the quantile with econometric theory and applied it to panel data. The quantile model is defined as following.

Suppose $Y$ is a continuous random variable and its distribution function is

Table 5. Summary statistics.

\begin{tabular}{cccccc}
\hline Variables & Mean & Std. Dev & Min & Max & Obs \\
\hline urb & 0.3479 & 0.1036 & 0.1218 & 0.6945 & 270 \\
tech & 0.1691 & 0.1520 & 0.0338 & 0.8389 & 270 \\
indus & 2.3472 & 0.1406 & 1.8700 & 2.8060 & 270 \\
gov & 0.3838 & 0.0373 & 0.2781 & 0.4943 & 270 \\
hr & 9.1539 & 0.8718 & 7.3360 & 12.5761 & 270 \\
trad & 0.2782 & 0.3191 & 0.0170 & 1.5293 & 270 \\
fin & 0.7476 & 0.1317 & 0.4085 & 1.1438 & 270 \\
\hline
\end{tabular}


$F(y)=P(Y \leq y)$, Then the $\tau$ quantile of $Y$ is defined as: $F\left(y_{\tau}\right)=P(Y \leq \tau)$. The quantile regression is expressed as follows:

$$
y_{\tau}\left(x_{i}\right)=x_{i}^{\prime} \beta_{\tau}
$$

where, $\beta_{\tau}$ is the regression coefficient of quantile $\tau$, its parameter estimation can be calculated as following:

$$
\min _{\beta_{\tau}} \sum_{i}^{n} \tau\left|y_{i}-x_{i}^{\prime} \beta_{\tau}\right|+\sum_{i}^{n}(1-\tau)\left|y_{i}-x_{i}^{\prime} \beta_{\tau}\right|
$$

Based on the above analysis, we specify the following function:

$$
u r b_{i t}=\alpha_{0}+\alpha_{1} \text { tech }_{i t}+\alpha_{2} \text { indus }_{i t}+\sum \alpha_{j} x_{i t}+\mu_{i t}
$$

where $i$ and $t$ refer to province and year, $u r b_{i t}$ stands for the level of regional new urbanization, tech $_{i t}$, indus $_{i t}$ represent the technological innovation and industrial structure upgrading respectively, $x_{i t}$ is other control variables, $\mu_{i t}$ denotes the random disturbance term.

\section{Empirical Results}

\subsection{Static Panel Regression and Quantile Regression Results}

Under different development stages of new urbanization, technological innovation and industrial structure upgrading have different impacts on new urbanization. We first used ordinary panel regression, and then used quantile regression method for analysis. In order to determine whether it is a fixed effect or a random effect model, it is necessary to perform the Hausman test. As the results reveal that the $\mathrm{P}$ value is 0.000 , so the fixed effects model is more appropriate. To provide a complete picture of different quantiles, nine quantiles $(0.1-0.9)$ are selected for analysis. The results of ordinary panel regression and quantile regression are summarized in Table 6 , and the trends of explanatory variable coefficients at each quantile are depicted in Figure 2.

In the fixed effect regression results in Table 6, technological innovation and industrial structure upgrading coefficients are positive, at 0.6360 and 0.1506 respectively. They have a significant effect on new urbanization at the $5 \%$ statistical level. Obviously, technological innovation and industrial structure upgrading have a significant role in promoting regional new urbanization. Technological innovation and industrial structure increase every $1 \%$, the new urbanization will increase $0.6360 \%$ and $0.1506 \%$ accordingly. Among the control variables, the coefficients of government welfare expenditure, human capital and financial development are significantly positive, indicating that all these variables contribute to the development of new urbanization.

From the quantile regression results and Figure 2, technological innovation coefficients are significantly positive at 0.1 to 0.9 quantiles. This indicates that technology investment can effectively promote the new urbanization. Observing the relationship between technological innovation and new urbanization, it is found that as the new urbanization increases, the impact of technological 
Table 6. Results of FE and panel quantile regression.

\begin{tabular}{|c|c|c|c|c|c|c|c|}
\hline Variable & tech & indus & gov & $\mathrm{hr}$ & trad & fin & hausman \\
\hline \multirow{2}{*}{ FE } & $0.6360^{* * *}$ & $0.1506^{* *}$ & $0.1755^{\star}$ & $0.0473^{\star * *}$ & 0.0023 & $0.1816^{\star * *}$ & $63.93^{\star * *}$ \\
\hline & $(0.0652)$ & $(0.0602)$ & $(0.1035)$ & $(0.0080)$ & $(0.0201)$ & $(0.0385)$ & \\
\hline \multirow{2}{*}{0.1} & $0.6744^{\star * *}$ & 0.1166 & 0.0734 & $0.0605^{\star * *}$ & 0.0095 & $0.1668^{* * *}$ & \\
\hline & $(0.1034)$ & $(0.1098)$ & $(0.1794)$ & $(0.0136)$ & $(0.0363)$ & $(0.0704)$ & \\
\hline \multirow{2}{*}{0.2} & $0.6606^{* * *}$ & 0.1288 & 0.1102 & $0.0557^{* * *}$ & 0.0069 & $0.1721^{\star * *}$ & \\
\hline & $(0.784)$ & $(0.0832)$ & $(0.1360)$ & $(0.0103)$ & $(0.0275)$ & $(0.0534)$ & \\
\hline \multirow{2}{*}{0.3} & $0.6536^{* * *}$ & $0.1350^{*}$ & 0.1285 & $0.0533^{* * *}$ & 0.0056 & $0.1748^{\star * *}$ & \\
\hline & $(0.0680)$ & $(0.0722)$ & $(0.1181)$ & $(0.0090)$ & $(0.0239)$ & $(0.0463)$ & \\
\hline \multirow{2}{*}{0.4} & $0.6464^{* * *}$ & $0.1414^{* *}$ & 0.1478 & $0.0509^{* * *}$ & 0.0042 & $0.1776^{\star * *}$ & \\
\hline & $(0.0597)$ & $(0.0634)$ & $(0.1037)$ & $(0.0079)$ & $(0.0209)$ & $(0.0406)$ & \\
\hline \multirow{2}{*}{ QR } & $0.6366^{* * *}$ & $0.1501^{* * *}$ & $0.1738^{\star}$ & $0.0474^{* * *}$ & 0.0024 & $0.1813^{* * *}$ & \\
\hline & $(0.0548)$ & $(0.0581)$ & $(0.0952)$ & $(0.0072)$ & $(0.0192)$ & $(0.0372)$ & \\
\hline \multirow{2}{*}{0.6} & $0.6271^{* * *}$ & $0.1585^{\star *}$ & $0.1993^{* *}$ & $0.0442^{* * *}$ & 0.0006 & $0.1850^{\star * *}$ & \\
\hline & $(0.0584)$ & $(0.0620)$ & $(0.1013)$ & $(0.0077)$ & $(0.0204)$ & $(0.0397)$ & \\
\hline \multirow{2}{*}{0.7} & $0.6188^{\star * *}$ & $0.1658^{\star *}$ & $0.2113^{*}$ & $0.0414^{* * *}$ & -0.0009 & $0.1882^{* * *}$ & \\
\hline & $(0.0673)$ & $(0.0714)$ & $(0.1168)$ & $(0.0089)$ & $(0.0236)$ & $(0.0458)$ & \\
\hline \multirow{2}{*}{0.8} & $0.6101^{* * *}$ & $0.1735^{\star *}$ & $0.2443^{*}$ & $0.0384^{* * *}$ & -0.0026 & $0.1916^{* * *}$ & \\
\hline & $(0.0804)$ & $(0.0854)$ & $(0.1396)$ & $(0.0106)$ & $(0.0282)$ & $(0.0548)$ & \\
\hline \multirow{2}{*}{0.9} & $0.5983^{\star * *}$ & $0.1840^{*}$ & 0.2758 & $0.0343^{\star \star}$ & -0.0048 & $0.1961^{\star * *}$ & \\
\hline & $(0.1020)$ & $(0.1083)$ & $(0.1768)$ & $(0.0133)$ & $(0.0358)$ & $(0.0695)$ & \\
\hline
\end{tabular}

Note: ${ }^{* *},{ }^{* *}$ and ${ }^{*}$ indicate that the test was passed at the $1 \%, 5 \%$ and $10 \%$ significance levels, respectively, and the numbers in the parentheses represent the standard error.

innovation on new urbanization shows a decreasing marginal trend. When technological innovation ascending each $1 \%$, the new urbanization will increase by $0.6744 \%-0.5983 \%$ at the 0.1 to 0.9 quantiles point. That is to say, in regions where new urbanization is underdeveloped, scientific and technological innovation has a relatively greater role in promoting urbanization. The possible reason is that in regions with lower new urbanization, the service sector output value is also correspondingly lower. When science and technology investment increase, industry is significantly optimized and technology can be directly transformed into productivity. As a result, factors of production are redistributed among different industries, which also increase urban employment opportunities and promote the development of new urbanization. On the contrary, in areas with higher new urbanization, the technological innovation environment is better. But technological innovation achievements are not well transformed into practical driving forces, resulting in low driving efficiency for new urbanization.

Industrial structure upgrading coefficient is not statistically significant at 0.1 and 0.2 quantiles, but it has a significantly positive impact on the development 


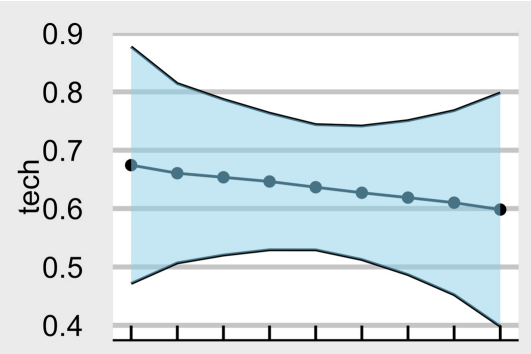

0.10 .20 .30 .40 .50 .60 .70 .80 .9 quantile

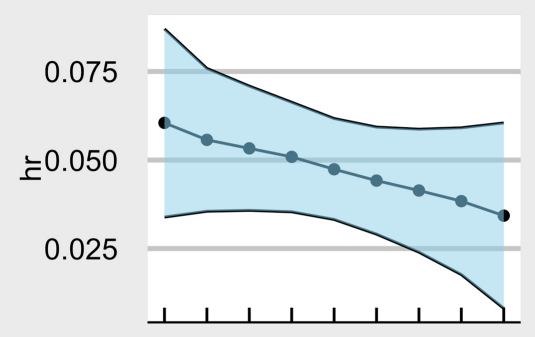

0.10 .20 .30 .40 .50 .60 .70 .80 .9 quantile
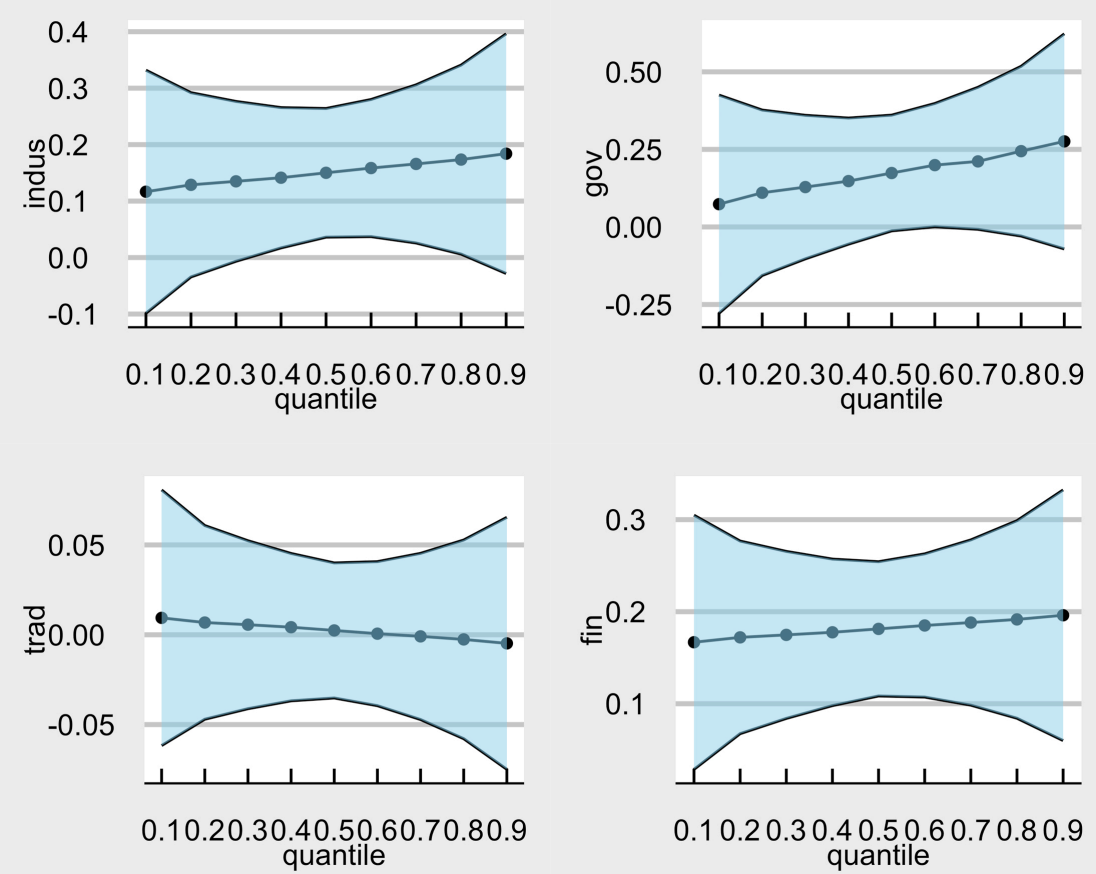

Figure 2. Variation of panel quantile regression coefficients.

of new urbanization at the $0.3-0.9$ quantiles. With the increase of the quantile from 0.3 to 0.9 , industrial structure upgrading coefficients are also increasing. When the industrial structure upgrading every $1 \%$, the new urbanization will increase by $0.135 \%$ at 0.3 quantile and it will be added to $0.184 \%$ at 0.9 quantile. It shows that the industrial structure cannot promote significantly the development of new urbanization when the new urbanization at a low level. When the new urbanization reaches some a certain level, the industrial structure plays a more and more significant role in promoting the development of new urbanization. The main reason is that the development of new urbanization is not only impacted by the industrial structure, but also impacted by other factors. In regions where the new urbanization is underdeveloped, the upgrading of industrial structure is not coordinated with the development of urbanization, which restricts the promotion of new urbanization.

For the control variables selected into the model, their impact on new urbanization varies from one to another. Human capital has a positive impact on the new urbanization at every quantile point. At $0.1,0.2,0.3,0.4$ and 0.9 quantiles, government welfare expenditure coefficients aren't significant. It indicates that government welfare expenditures at the moment cannot effectively promote the development of new urbanization. Therefore, government welfare expenditure policy in some areas of China may need to be adjusted appropriately to adapt to the development of new urbanization. The financial development efficiency coefficient of the model gradually increases with the increase of quantile. It can improve significantly the new urbanization at arbitrary quantile from 0.1 to 0.9 . It is obvious that to promote new urbanization is inseparable from the support 
of financial funds no matter what quantile point it stands. In any quantile point from 0.1 to 0.9 , trade opening has not a significant promoting effect on new urbanization. For China, the pattern that processing trade accounts for a large proportion of total trade value. This situation is deemed to maybe hinder industrial upgrading and economic transformation. Thereupon then it is not conducive to the sustainable development of new urbanization.

\subsection{Robustness Analysis}

The robustness of the method is dealt within this subsection. We replace the entropy method with the factor analysis method as another measurement method to obtain the representative value of new urbanization and scientific and technological innovation in the 30 provinces from 2010 to 2018. At the same time, we replace the industrial structure upgrading coefficient with the added value of the tertiary industry in GDP to obtain a different measure value of industrial structure upgrading. These results are given in Tables B1-B3 in Appendix B. A novel panel quantile regression result is disclosed in Table 7. It shows that the

Table 7. Robustness analysis results.

\begin{tabular}{|c|c|c|c|c|c|c|}
\hline Variable & tech & indus & gov & $\mathrm{hr}$ & trad & fin \\
\hline \multirow{2}{*}{0.1} & $0.5839^{* * *}$ & 0.9131 & -0.544 & $0.2696^{* * *}$ & 0.0528 & 0.5539 \\
\hline & $(0.1685)$ & $(0.9147)$ & $(1.3390)$ & $(0.1029)$ & $(0.2537)$ & $(0.5269)$ \\
\hline \multirow{2}{*}{0.2} & $0.5712^{* * *}$ & 0.9436 & -0.3391 & $0.2395^{* * *}$ & 0.0357 & 0.6392 \\
\hline & $(0.1295)$ & $(0.7033)$ & (1.0293) & $(0.0790)$ & $(0.1951)$ & $(0.4050)$ \\
\hline \multirow{2}{*}{0.3} & $0.5642^{* * *}$ & 0.9593 & -0.2233 & $0.2226^{* * *}$ & 0.0261 & $0.6874^{\star *}$ \\
\hline & $(0.1093)$ & $(0.5931)$ & $(0.8682)$ & $(0.0667)$ & $(0.1645)$ & $(0.3416)$ \\
\hline \multirow{2}{*}{0.4} & $0.5573^{* * *}$ & $0.9754^{* *}$ & -0.1117 & $0.2062^{* * *}$ & 0.0168 & $0.7339^{\star *}$ \\
\hline & $(0.0919)$ & $(0.4985)$ & $(0.7309)$ & $(0.0564)$ & $(0.1383)$ & $(0.2877)$ \\
\hline \multirow{2}{*}{0.5} & $0.5482^{* * *}$ & $0.9966^{* *}$ & 0.0355 & $0.1846^{* * *}$ & 0.0045 & $0.7952^{\star * *}$ \\
\hline & $(0.0747)$ & $(0.4051)$ & $(0.5950)$ & $(0.0461)$ & $(0.1125)$ & $(0.2343)$ \\
\hline \multirow{2}{*}{0.6} & $0.5395^{\star * *}$ & $1.0169^{* * *}$ & 0.1766 & $0.1639^{* * *}$ & -0.0072 & $0.8539^{* * *}$ \\
\hline & $(0.0687)$ & $(0.3722)$ & $(0.5473)$ & $(0.0425)$ & $(0.1033)$ & $(0.2156)$ \\
\hline \multirow{2}{*}{0.7} & $0.5321^{* * *}$ & $1.034^{* * *}$ & 0.2983 & $0.1461^{* * *}$ & -0.0173 & $0.9045^{* * *}$ \\
\hline & $(0.0737)$ & $(0.3999)$ & $(0.5867)$ & $(0.0453)$ & $(0.1110)$ & $(0.2309)$ \\
\hline \multirow{2}{*}{0.8} & $0.5254^{* * *}$ & $1.0498^{\star *}$ & 0.4056 & $0.1304^{* * *}$ & -0.0262 & $0.9491^{\star * *}$ \\
\hline & $(0.0849)$ & $(0.4606)$ & $(0.6748)$ & $(0.0520)$ & $(0.1277)$ & $(0.2656)$ \\
\hline \multirow{2}{*}{0.9} & $0.5167^{\star * *}$ & $1.0702^{\star}$ & 0.5472 & $0.1096^{*}$ & -0.0381 & $1.008^{* * *}$ \\
\hline & $(0.1057)$ & $(0.5736)$ & $(0.8398)$ & $(0.0645)$ & $(0.1591)$ & $(0.3304)$ \\
\hline
\end{tabular}

Note: ${ }^{* *},{ }^{* *}$ and ${ }^{*}$ indicate that the test was passed at the $1 \%, 5 \%$ and $10 \%$ significance levels, respectively, and the numbers in the parentheses represent the standard error. 
trends of core explanatory variable coefficients are consistent with the previous panel quantile regression model results. Technological innovation to the new urbanization is still statistically significant positive. The parameter estimation of industrial structure upgrading is larger than the counterpart in Subsection 4.2, but the trend of the effect is similar. The coefficient of industrial structure upgrading is still not significant at low quantile and it is significantly positive when the quantile is bigger than 0.4. In addition, compared with the consequence that obtained in the previous section, the coefficients of control variables do not vary much. From this, we can declare that the conclusion of this paper on the relationship among technological innovation, industrial structure upgrading and new urbanization is relatively reliable.

\section{Conclusion and Policy Implications}

Based on the data of the 30 provinces in Mainland of China from 2010 to 2018, this paper empirically analyzes the role of technological innovation and industrial structure upgrading on new urbanization by constructing a panel quantile regression model. First, the comprehensive index of new urbanization, technological innovation and industrial structure upgrading is calculated by using the entropy method and structural changes. Then, a panel quantile regression model is built to quantitatively analyze the effect of technological innovation and industrial structure upgrading on new urbanization. In the process of the development of new urbanization, technological innovation has a significantly positive impact on new urbanization is. But, with the increase of quantile, the impact of scientific and technological innovation on new urbanization is a marginal decrease. When the quantile is greater than 0.3 , the industrial structure upgrading has a significant positive impact on new urbanization and the coefficient increases with the quantile increasing. This effect is not observed at the 0.1 and 0.2 quantile. Based on traditional fixed effect model, we can't obtain similar details. Furthermore, the control variables also have different effects on new urbanization. Both human capital and financial development have positive effects. Government welfare expenditure can promote new urbanization at the quantile from 0.5 to 0.8 . Trade openness doesn't a significant effect on new urbanization.

Based on the conclusion of this paper, we propose the following advices to promote new urbanization. Firstly, it is necessary to increase the investment in basic research. Although its marginal effect tends to decline, technological innovation on new urbanization has a positive effect on every quantile. Only by continuously implementing this basic, long-term and comprehensive strategy will we be able to strengthen the training of scientific and technological talents, improve the scientific and technological innovation environment, increase various welfare benefits, and attract foreign scientific and technological talents, so as to provide continuous intellectual and technical support for the development of new urbanization. Secondly, we will unswervingly promote the upgrading of the industrial structure. In the process of new urbanization, the importance of in- 
dustrial upgrading is gradually emerging. Therefore, we should continue to give play to the leading role of industry in the process of new urbanization, promote industrial innovation through science and technology, reasonably optimize industrial layout adjustment, vigorously develop new industry and tertiary industry, and further expand jobs to attract rural working population to cities and towns.

\section{Foundation Project}

National Natural Science Foundation of China (61763008, 71762008, 62166015); Guangxi Science and Technology Planning Project (2018GXNSFAA294131, 2018GXNSFAA050005).

\section{Conflicts of Interest}

The authors declare no conflicts of interest regarding the publication of this paper.

\section{References}

Andersson, R., Quigley, J. M., \& Wilhelmsson, M. (2009). Urbanization, Productivity, and Innovation: Evidence from Investment in Higher Education. Journal of Urban Economics, 66, 2-15. https://doi.org/10.1016/j.jue.2009.02.004

Bertinelli, L., \& Strobl, E. (2007). Urbanisation, Urban Concentration and Economic Development. Urban Studies, 44, 2499-2510. https://doi.org/10.1080/00420980701558442

Carlino, G. A., Chatterjee, S., \& Hunt, R. M. (2007). Urban Density and the Rate of Invention. Journal of Urban Economics, 61, 389-419. https://doi.org/10.1016/j.jue.2006.08.003

Chen, M. X., Gong, Y. H., Lu, D. D., \& Ye, C. (2019). Build a People-Oriented Urbanization: China's New-Type Urbanization Dream and Anhui Model. Land Use Policy, 80, 1-9. https://doi.org/10.1016/j.landusepol.2018.09.031

Davis, J. C., \& Henderson, J. V. (2003). Evidence on the Political Economy of the Urbanization Process. Journal of Urban Economics, 53, 98-125. https://doi.org/10.1016/S0094-1190(02)00504-1

Gan, L., Shi, H., Yuan, H., Lev, B., \& Lan, H. X. (2020). Coupling Coordination Degree for Urbanization City-Industry Integration Level: Sichuan Case. Sustainable Cities and Society, 58, Article ID: 102136. https://doi.org/10.1016/j.scs.2020.102136

Guan, X. L., Wei, H. K., Lu, S. S., Dai, Q., \& S, H. J. (2018). Assessment on the Urbanization Strategy in China: Achievements, Challenges and Reflections. Habitat International, 71, 97-109. https://doi.org/10.1016/j.habitatint.2017.11.009

Kijek, A., \& Kijek, T. (2010). The Analysis of Innovation Input-Output Relationships in EU Member States. Comparative Economic Research, 13, 93-106. https://doi.org/10.2478/v10103-009-0040-5

Koenker, R. (2004). Quantile Regression for Longitudinal Data. Journal of Multivariate Analysis, 91, 74-89. https://doi.org/10.1016/j.jmva.2004.05.006

Koenker, R., \& Bassett, G. (1978). Quantile Regressions. Econometrica, 46, 33-50. https://doi.org/10.2307/1913643

Lee, J., \& Lee, H. (2016). Human Capital in the Long Run. Journal of Development Eco- 
nomics, 122, 147-169. https://doi.org/10.1016/j.jdeveco.2016.05.006

Li, C. X., \& Li, G. Z. (2020). Does Environmental Regulation Reduce China's Haze Pollution? An Empirical Analysis Based on Panel Quantile Regression. PLoS ONE, 15, e240723. https://doi.org/10.1371/journal.pone.0240723

Lv, C. C., Shao, C. H., \& Lee, C. C. (2021). Green Technology Innovation and Financial Development: Do Environmental Regulation and Innovation Output Matter? Energy Economics, 98, Article ID: 105237. https://doi.org/10.1016/j.eneco.2021.105237

Murakami, N. (2015). Changes in Japanese Industrial Structure and Urbanization: Evidence from Prefectural Data. Journal of the Asia Pacific Economy, 20, 385-403. https://doi.org/10.1080/13547860.2015.1054166

Shang, J., Wang, Z., Li, L., Chen, Y., \& Li, P. F. (2018). A Study on the Correlation between Technology Innovation and the New-Type Urbanization in Shaanxi Province. Technological Forecasting and Social Change, 135, 266-273. https://doi.org/10.1016/j.techfore.2018.04.029

Song, Z. Y., \& Zhu, Q. L. (2020). Spatio-Temporal Pattern and Driving Forces of Urbanization in China's Border Areas. Journal of Geographical Sciences, 30, 775-793. https://doi.org/10.1007/s11442-020-1755-2

Trip, J. J. (2013). Stefan Krätke: The Creative Capital of Cities: Interactive Knowledge Creation and the Urbanization Economies of Innovation. Journal of Housing and the Built Environment, 28, 411-412. https://doi.org/10.1007/s10901-012-9308-3

Wang, F., Tian, M., \& Yin, Z. H. (2021). Modern Urbanization and Industrial Upgrading in China: Evidence from Panel Data. Quality\& Quantity, 55, 661-681.

https://doi.org/10.1007/s11135-020-01022-5

Wu, Y. J., Dong, S. C., Zhai, J., Huang, D. X., \& Huang, X. Y. (2016). Land Management Institution as a Key Confinement of Urbanization in Baotou, China-Application of Proposed Endogenous Urbanization Model. Land Use Policy, 57, 348-355.

https://doi.org/10.1016/j.landusepol.2016.04.021

Yu, X., \& Wang, P. (2021). Economic Effects Analysis of Environmental Regulation Policy in the Process of Industrial Structure Upgrading: Evidence from Chinese Provincial Panel Data. Science of the Total Environment, 753, Article ID: 142004. https://doi.org/10.1016/j.scitotenv.2020.142004

Zhang, J. X., Chang, Y., Zhang, L. X., \& Li, D. (2018). Do Technological Innovations Promote Urban Green Development?-A Spatial Econometric Analysis of 105 Cities in China. Journal of Cleaner Production, 182, 395-403.

https://doi.org/10.1016/j.jclepro.2018.02.067

Zou, X., Cao, G., Jiang, J., \& Liu, X. Y. (2016). Assessing the Effect of the Integration among the Urbanization and Industries Development in Three Gorges Reservoir Area in China Based on P-VAR Models. Journal of Urban Planning and Development, 142, Article ID: 4015015. https://doi.org/10.1061/(ASCE)UP.1943-5444.0000306 
Appendix A. Technological Innovation and Industrial Structure Upgrading Index in Section 3.1

Table A1. The technology innovation level of the 30 provinces from 2010 to 2018.

\begin{tabular}{|c|c|c|c|c|c|c|c|c|c|}
\hline Year & 2010 & 2011 & 2012 & 2013 & 2014 & 2015 & 2016 & 2017 & 2018 \\
\hline Beijing & 0.589 & 0.629 & 0.680 & 0.712 & 0.732 & 0.735 & 0.754 & 0.804 & 0.839 \\
\hline Tianjin & 0.255 & 0.283 & 0.307 & 0.332 & 0.349 & 0.385 & 0.368 & 0.334 & 0.356 \\
\hline Hubei & 0.046 & 0.053 & 0.063 & 0.069 & 0.076 & 0.081 & 0.091 & 0.100 & 0.110 \\
\hline Shanxi & 0.058 & 0.063 & 0.068 & 0.084 & 0.078 & 0.062 & 0.067 & 0.080 & 0.095 \\
\hline $\begin{array}{c}\text { Inner } \\
\text { Mongolia }\end{array}$ & 0.034 & 0.039 & 0.048 & 0.047 & 0.045 & 0.049 & 0.053 & 0.054 & 0.047 \\
\hline Liaoning & 0.134 & 0.156 & 0.153 & 0.159 & 0.153 & 0.132 & 0.157 & 0.163 & 0.178 \\
\hline Jilin & 0.086 & 0.101 & 0.095 & 0.084 & 0.093 & 0.107 & 0.121 & 0.129 & 0.119 \\
\hline Heilongjiang & 0.093 & 0.090 & 0.095 & 0.095 & 0.098 & 0.092 & 0.090 & 0.089 & 0.078 \\
\hline Shanghai & 0.409 & 0.428 & 0.445 & 0.457 & 0.466 & 0.456 & 0.479 & 0.500 & 0.528 \\
\hline Jiangsu & 0.232 & 0.282 & 0.325 & 0.347 & 0.351 & 0.355 & 0.367 & 0.374 & 0.400 \\
\hline Zhejiang & 0.216 & 0.257 & 0.291 & 0.323 & 0.335 & 0.353 & 0.371 & 0.380 & 0.419 \\
\hline Anhui & 0.112 & 0.135 & 0.149 & 0.168 & 0.182 & 0.193 & 0.225 & 0.232 & 0.245 \\
\hline Fujian & 0.115 & 0.139 & 0.147 & 0.156 & 0.163 & 0.167 & 0.180 & 0.197 & 0.220 \\
\hline Jiangxi & 0.059 & 0.062 & 0.067 & 0.080 & 0.089 & 0.096 & 0.115 & 0.140 & 0.169 \\
\hline Shandong & 0.139 & 0.158 & 0.173 & 0.188 & 0.191 & 0.192 & 0.198 & 0.211 & 0.204 \\
\hline Henan & 0.059 & 0.070 & 0.073 & 0.088 & 0.092 & 0.096 & 0.100 & 0.110 & 0.117 \\
\hline Hubei & 0.124 & 0.146 & 0.159 & 0.182 & 0.205 & 0.211 & 0.222 & 0.238 & 0.261 \\
\hline Hunan & 0.087 & 0.103 & 0.110 & 0.125 & 0.126 & 0.137 & 0.137 & 0.159 & 0.169 \\
\hline Guangdong & 0.247 & 0.274 & 0.304 & 0.333 & 0.326 & 0.368 & 0.407 & 0.431 & 0.499 \\
\hline Guangxi & 0.047 & 0.060 & 0.062 & 0.067 & 0.064 & 0.059 & 0.058 & 0.065 & 0.062 \\
\hline Hainan & 0.034 & 0.039 & 0.044 & 0.050 & 0.047 & 0.045 & 0.045 & 0.040 & 0.045 \\
\hline Chongqing & 0.137 & 0.132 & 0.127 & 0.140 & 0.159 & 0.169 & 0.191 & 0.189 & 0.200 \\
\hline Sichuan & 0.082 & 0.091 & 0.096 & 0.111 & 0.117 & 0.128 & 0.132 & 0.140 & 0.174 \\
\hline Guizhou & 0.057 & 0.056 & 0.056 & 0.057 & 0.058 & 0.060 & 0.064 & 0.075 & 0.088 \\
\hline Yunnan & 0.034 & 0.040 & 0.043 & 0.046 & 0.049 & 0.055 & 0.058 & 0.061 & 0.064 \\
\hline Shaanxi & 0.138 & 0.156 & 0.165 & 0.189 & 0.195 & 0.209 & 0.222 & 0.225 & 0.233 \\
\hline Gansu & 0.071 & 0.071 & 0.078 & 0.086 & 0.092 & 0.093 & 0.089 & 0.089 & 0.090 \\
\hline Qinghai & 0.041 & 0.042 & 0.049 & 0.049 & 0.045 & 0.055 & 0.060 & 0.076 & 0.080 \\
\hline Ningxia & 0.069 & 0.074 & 0.074 & 0.077 & 0.076 & 0.083 & 0.082 & 0.104 & 0.120 \\
\hline Xinjiang & 0.039 & 0.045 & 0.043 & 0.046 & 0.047 & 0.047 & 0.049 & 0.042 & 0.038 \\
\hline
\end{tabular}


Table A2. The industrial structure upgrading index of the30 provinces from 2010 to 2018.

\begin{tabular}{|c|c|c|c|c|c|c|c|c|c|}
\hline Year & 2010 & 2011 & 2012 & 2013 & 2014 & 2015 & 2016 & 2017 & 2018 \\
\hline Beijing & 2.750 & 2.759 & 2.763 & 2.768 & 2.774 & 2.792 & 2.798 & 2.802 & 2.806 \\
\hline Tianjin & 2.445 & 2.447 & 2.456 & 2.470 & 2.483 & 2.509 & 2.560 & 2.572 & 2.577 \\
\hline Hubei & 2.224 & 2.233 & 2.241 & 2.253 & 2.267 & 2.301 & 2.323 & 2.350 & 2.397 \\
\hline Shanxi & 2.313 & 2.297 & 2.330 & 2.364 & 2.387 & 2.475 & 2.501 & 2.471 & 2.490 \\
\hline $\begin{array}{c}\text { Inner } \\
\text { Mongolia }\end{array}$ & 2.269 & 2.258 & 2.263 & 2.270 & 2.304 & 2.314 & 2.347 & 2.397 & 2.403 \\
\hline Liaoning & 2.283 & 2.281 & 2.294 & 2.301 & 2.338 & 2.379 & 2.418 & 2.444 & 2.443 \\
\hline Jilin & 2.238 & 2.227 & 2.229 & 2.249 & 2.252 & 2.274 & 2.324 & 2.383 & 2.421 \\
\hline Heilongjiang & 2.212 & 2.170 & 2.251 & 2.224 & 2.286 & 2.334 & 2.367 & 2.372 & 2.388 \\
\hline Shanghai & 2.559 & 2.564 & 2.588 & 2.634 & 2.631 & 2.660 & 2.695 & 2.689 & 2.696 \\
\hline Jiangsu & 2.352 & 2.360 & 2.369 & 2.394 & 2.410 & 2.426 & 2.448 & 2.456 & 2.465 \\
\hline Zhejiang & 2.388 & 2.393 & 2.413 & 2.419 & 2.425 & 2.447 & 2.461 & 2.482 & 2.496 \\
\hline Anhui & 2.199 & 2.194 & 2.200 & 2.224 & 2.239 & 2.279 & 2.307 & 2.334 & 2.363 \\
\hline Fujian & 2.311 & 2.306 & 2.309 & 2.312 & 2.309 & 2.326 & 2.346 & 2.378 & 2.380 \\
\hline Jiangxi & 2.203 & 2.219 & 2.233 & 2.247 & 2.265 & 2.289 & 2.325 & 2.335 & 2.364 \\
\hline Shandong & 2.274 & 2.295 & 2.313 & 2.337 & 2.353 & 2.371 & 2.396 & 2.413 & 2.430 \\
\hline Henan & 2.172 & 2.197 & 2.218 & 2.238 & 2.257 & 2.294 & 2.319 & 2.341 & 2.363 \\
\hline Hubei & 2.271 & 2.262 & 2.270 & 2.305 & 2.327 & 2.347 & 2.360 & 2.388 & 2.412 \\
\hline Hunan & 2.265 & 2.259 & 2.274 & 2.308 & 2.327 & 2.352 & 2.380 & 2.407 & 2.433 \\
\hline Guangdong & 2.407 & 2.419 & 2.437 & 2.447 & 2.433 & 2.448 & 2.486 & 2.506 & 2.519 \\
\hline Guangxi & 2.179 & 2.167 & 2.188 & 2.217 & 2.225 & 2.236 & 2.244 & 2.285 & 2.307 \\
\hline Hainan & 2.222 & 2.212 & 2.242 & 2.295 & 2.300 & 2.316 & 2.327 & 2.350 & 2.384 \\
\hline Chongqing & 2.389 & 2.394 & 2.390 & 2.396 & 2.401 & 2.417 & 2.431 & 2.451 & 2.462 \\
\hline Sichuan & 2.256 & 2.242 & 2.257 & 2.275 & 2.302 & 2.315 & 2.354 & 2.381 & 2.405 \\
\hline Guizhou & 2.337 & 2.361 & 2.349 & 2.337 & 2.307 & 2.293 & 2.290 & 2.299 & 2.320 \\
\hline Yunnan & 2.245 & 2.257 & 2.251 & 2.256 & 2.277 & 2.301 & 2.318 & 2.336 & 2.332 \\
\hline Shaanxi & 2.266 & 2.250 & 2.252 & 2.252 & 2.282 & 2.319 & 2.336 & 2.344 & 2.351 \\
\hline Gansu & 2.228 & 2.256 & 2.264 & 2.270 & 2.308 & 2.352 & 2.378 & 2.426 & 2.438 \\
\hline Qinghai & 1.923 & 1.870 & 1.894 & 1.877 & 1.979 & 2.085 & 2.138 & 2.282 & 2.303 \\
\hline Ningxia & 2.320 & 2.320 & 2.332 & 2.322 & 2.358 & 2.366 & 2.378 & 2.396 & 2.404 \\
\hline Xinjiang & 2.128 & 2.177 & 2.195 & 2.255 & 2.262 & 2.303 & 2.307 & 2.316 & 2.319 \\
\hline
\end{tabular}




\section{Appendix B. Data for Robustness Analysis in Section 4.3}

Table B1. The new urbanization measure value of the 30 provinces from 2010 to 2018.

\begin{tabular}{|c|c|c|c|c|c|c|c|c|c|}
\hline Year & 2010 & 2011 & 2012 & 2013 & 2014 & 2015 & 2016 & 2017 & 2018 \\
\hline Beijing & 0.78 & 0.90 & 0.84 & 1.14 & 1.16 & 1.24 & 1.34 & 1.49 & 1.53 \\
\hline Tianjin & 0.11 & 0.27 & 0.29 & 0.45 & 0.38 & 0.45 & 0.48 & 0.73 & 0.40 \\
\hline Hubei & -0.21 & -0.19 & -0.14 & -0.04 & 0.05 & 0.15 & 0.17 & 0.33 & 0.38 \\
\hline Shanxi & -0.28 & -0.25 & -0.19 & -0.13 & -0.11 & -0.10 & -0.02 & 0.08 & 0.17 \\
\hline $\begin{array}{c}\text { Inner } \\
\text { Mongolia }\end{array}$ & -0.20 & -0.07 & 0.04 & 0.12 & 0.29 & 0.35 & 0.36 & 0.34 & 0.37 \\
\hline Liaoning & -0.11 & -0.06 & 0.02 & 0.11 & 0.15 & 0.20 & 0.06 & 0.19 & 0.18 \\
\hline Jilin & -0.28 & -0.20 & -0.17 & -0.13 & 0.01 & -0.02 & 0.06 & 0.07 & 0.17 \\
\hline Heilongjiang & -0.38 & -0.33 & -0.31 & -0.26 & -0.27 & -0.24 & -0.26 & -0.16 & -0.15 \\
\hline Shanghai & 0.23 & 0.34 & 0.27 & 0.43 & 0.37 & 0.42 & 0.50 & 0.66 & 0.74 \\
\hline Jiangsu & 0.25 & 0.33 & 0.41 & 0.52 & 0.60 & 0.69 & 0.75 & 0.83 & 0.89 \\
\hline Zhejiang & 0.18 & 0.26 & 0.32 & 0.43 & 0.52 & 0.59 & 0.63 & 0.72 & 0.79 \\
\hline Anhui & -0.52 & -0.38 & -0.32 & -0.24 & -0.12 & -0.05 & 0.01 & 0.15 & 0.31 \\
\hline Fujian & -0.24 & -0.16 & -0.06 & 0.02 & 0.10 & 0.19 & 0.27 & 0.35 & 0.45 \\
\hline Jiangxi & -0.41 & -0.33 & -0.24 & -0.20 & -0.18 & -0.12 & -0.01 & 0.09 & 0.16 \\
\hline Shandong & 0.06 & 0.13 & 0.26 & 0.40 & 0.43 & 0.51 & 0.58 & 0.65 & 0.67 \\
\hline Henan & -0.68 & -0.62 & -0.51 & -0.47 & -0.35 & -0.25 & -0.15 & 0.00 & 0.18 \\
\hline Hubei & -0.36 & -0.31 & -0.24 & -0.20 & -0.09 & 0.00 & 0.05 & 0.11 & 0.30 \\
\hline Hunan & -0.57 & -0.41 & -0.46 & -0.41 & -0.30 & -0.21 & -0.15 & -0.10 & 0.06 \\
\hline Guangdong & 0.30 & 0.39 & 0.43 & 0.56 & 0.63 & 0.69 & 0.76 & 0.87 & 0.99 \\
\hline Guangxi & -0.74 & -0.66 & -0.57 & -0.53 & -0.36 & -0.28 & -0.25 & -0.17 & -0.06 \\
\hline Hainan & -0.61 & -0.39 & -0.38 & -0.28 & -0.21 & -0.21 & -0.14 & -0.09 & 0.01 \\
\hline Chongqing & -0.34 & -0.12 & 0.03 & 0.05 & 0.09 & 0.18 & 0.23 & 0.32 & 0.47 \\
\hline Sichuan & -0.54 & -0.46 & -0.35 & -0.28 & -0.20 & -0.08 & -0.04 & 0.05 & 0.17 \\
\hline Guizhou & -1.08 & -1.01 & -0.88 & -0.74 & -0.54 & -0.45 & -0.27 & -0.21 & -0.11 \\
\hline Yunnan & -0.87 & -0.78 & -0.74 & -0.67 & -0.54 & -0.48 & -0.37 & -0.27 & -0.19 \\
\hline Shaanxi & -0.59 & -0.50 & -0.43 & -0.35 & -0.23 & -0.09 & -0.07 & 0.05 & 0.11 \\
\hline Gansu & -0.90 & -0.79 & -0.78 & -0.65 & -0.55 & -0.53 & -0.46 & -0.33 & -0.22 \\
\hline Qinghai & -0.54 & -0.41 & -0.36 & -0.23 & -0.20 & -0.09 & -0.09 & -0.04 & 0.03 \\
\hline Ningxia & -0.18 & -0.16 & -0.13 & -0.05 & 0.08 & 0.13 & 0.17 & 0.34 & 0.45 \\
\hline Xinjiang & -0.69 & -0.59 & -0.53 & -0.45 & -0.33 & -0.21 & -0.13 & -0.06 & 0.05 \\
\hline
\end{tabular}


Table B2. The science and technology innovation level of the 30 provinces from 2010 to 2018.

\begin{tabular}{|c|c|c|c|c|c|c|c|c|c|}
\hline Year & 2010 & 2011 & 2012 & 2013 & 2014 & 2015 & 2016 & 2017 & 2018 \\
\hline Beijing & 1.98 & 2.10 & 2.24 & 2.35 & 2.43 & 2.39 & 2.42 & 2.62 & 2.77 \\
\hline Tianjin & 0.57 & 0.69 & 0.80 & 0.91 & 0.95 & 1.09 & 0.98 & 0.80 & 0.88 \\
\hline Hubei & -0.59 & -0.56 & -0.50 & -0.47 & -0.43 & -0.41 & -0.36 & -0.31 & -0.27 \\
\hline Shanxi & -0.52 & -0.49 & -0.45 & -0.37 & -0.39 & -0.49 & -0.47 & -0.42 & -0.36 \\
\hline $\begin{array}{c}\text { Inner } \\
\text { Mongolia }\end{array}$ & -0.67 & -0.64 & -0.61 & -0.59 & -0.60 & -0.59 & -0.57 & -0.56 & -0.60 \\
\hline Liaoning & -0.12 & -0.01 & -0.03 & 0.02 & -0.02 & -0.15 & -0.04 & -0.01 & 0.05 \\
\hline Jilin & -0.36 & -0.28 & -0.30 & -0.35 & -0.30 & -0.22 & -0.19 & -0.18 & -0.25 \\
\hline Heilongjiang & -0.34 & -0.37 & -0.35 & -0.35 & -0.34 & -0.37 & -0.39 & -0.40 & -0.46 \\
\hline Shanghai & 1.26 & 1.31 & 1.38 & 1.44 & 1.47 & 1.40 & 1.49 & 1.61 & 1.69 \\
\hline Jiangsu & 0.37 & 0.61 & 0.81 & 0.90 & 0.93 & 0.94 & 0.99 & 1.03 & 1.14 \\
\hline Zhejiang & 0.25 & 0.44 & 0.61 & 0.75 & 0.81 & 0.88 & 0.95 & 0.98 & 1.14 \\
\hline Anhui & -0.26 & -0.14 & -0.06 & 0.03 & 0.10 & 0.15 & 0.32 & 0.34 & 0.40 \\
\hline Fujian & -0.25 & -0.13 & -0.09 & -0.03 & 0.01 & 0.01 & 0.07 & 0.14 & 0.25 \\
\hline Jiangxi & -0.52 & -0.51 & -0.47 & -0.40 & -0.35 & -0.31 & -0.21 & -0.08 & 0.06 \\
\hline Shandong & -0.10 & -0.01 & 0.07 & 0.15 & 0.16 & 0.17 & 0.20 & 0.25 & 0.19 \\
\hline Henan & -0.53 & -0.48 & -0.45 & -0.37 & -0.35 & -0.33 & -0.31 & -0.24 & -0.20 \\
\hline Hubei & -0.15 & -0.04 & 0.02 & 0.11 & 0.21 & 0.21 & 0.25 & 0.32 & 0.44 \\
\hline Hunan & -0.39 & -0.30 & -0.26 & -0.20 & -0.19 & -0.14 & -0.13 & -0.02 & 0.04 \\
\hline Guangdong & 0.37 & 0.50 & 0.64 & 0.79 & 0.77 & 0.97 & 1.17 & 1.27 & 1.58 \\
\hline Guangxi & -0.62 & -0.55 & -0.52 & -0.49 & -0.50 & -0.52 & -0.53 & -0.48 & -0.49 \\
\hline Hainan & -0.66 & -0.63 & -0.59 & -0.56 & -0.58 & -0.59 & -0.59 & -0.62 & -0.59 \\
\hline Chongqing & -0.14 & -0.15 & -0.16 & -0.09 & -0.01 & 0.07 & 0.16 & 0.18 & 0.20 \\
\hline Sichuan & -0.42 & -0.38 & -0.35 & -0.28 & -0.25 & -0.20 & -0.18 & -0.15 & -0.03 \\
\hline Guizhou & -0.61 & -0.60 & -0.59 & -0.58 & -0.57 & -0.55 & -0.51 & -0.47 & -0.41 \\
\hline Yunnan & -0.69 & -0.66 & -0.65 & -0.63 & -0.61 & -0.58 & -0.55 & -0.53 & -0.51 \\
\hline Shaanxi & -0.07 & -0.01 & 0.02 & 0.10 & 0.12 & 0.17 & 0.22 & 0.23 & 0.26 \\
\hline Gansu & -0.51 & -0.50 & -0.46 & -0.44 & -0.41 & -0.41 & -0.44 & -0.44 & -0.44 \\
\hline Qinghai & -0.71 & -0.72 & -0.68 & -0.68 & -0.70 & -0.68 & -0.66 & -0.59 & -0.59 \\
\hline Ningxia & -0.49 & -0.47 & -0.45 & -0.43 & -0.43 & -0.40 & -0.40 & -0.29 & -0.21 \\
\hline Xinjiang & -0.67 & -0.64 & -0.64 & -0.62 & -0.61 & -0.61 & -0.60 & -0.63 & -0.65 \\
\hline
\end{tabular}


L. F. Wei et al.

Table B3. The industrial structure upgrading index of the 30 provinces from 2010 to 2018.

\begin{tabular}{|c|c|c|c|c|c|c|c|c|c|}
\hline Year & 2010 & 2011 & 2012 & 2013 & 2014 & 2015 & 2016 & 2017 & 2018 \\
\hline Beijing & 0.75 & 0.76 & 0.76 & 0.77 & 0.78 & 0.80 & 0.80 & 0.81 & 0.81 \\
\hline Tianjin & 0.46 & 0.46 & 0.47 & 0.48 & 0.50 & 0.52 & 0.56 & 0.58 & 0.59 \\
\hline Hubei & 0.35 & 0.35 & 0.35 & 0.35 & 0.37 & 0.40 & 0.42 & 0.44 & 0.46 \\
\hline Shanxi & 0.37 & 0.35 & 0.39 & 0.40 & 0.44 & 0.53 & 0.55 & 0.52 & 0.53 \\
\hline $\begin{array}{c}\text { Inner } \\
\text { Mongolia }\end{array}$ & 0.36 & 0.35 & 0.35 & 0.37 & 0.40 & 0.40 & 0.44 & 0.50 & 0.50 \\
\hline Liaoning & 0.37 & 0.37 & 0.38 & 0.39 & 0.42 & 0.46 & 0.52 & 0.53 & 0.52 \\
\hline Jilin & 0.36 & 0.35 & 0.35 & 0.36 & 0.36 & 0.39 & 0.42 & 0.46 & 0.50 \\
\hline Heilongjiang & 0.37 & 0.36 & 0.40 & 0.41 & 0.46 & 0.51 & 0.54 & 0.56 & 0.57 \\
\hline Shanghai & 0.57 & 0.58 & 0.60 & 0.62 & 0.65 & 0.68 & 0.70 & 0.69 & 0.70 \\
\hline Jiangsu & 0.41 & 0.42 & 0.44 & 0.45 & 0.47 & 0.49 & 0.50 & 0.50 & 0.51 \\
\hline Zhejiang & 0.44 & 0.44 & 0.45 & 0.46 & 0.48 & 0.50 & 0.51 & 0.53 & 0.55 \\
\hline Anhui & 0.34 & 0.33 & 0.33 & 0.33 & 0.35 & 0.39 & 0.41 & 0.43 & 0.45 \\
\hline Fujian & 0.40 & 0.39 & 0.39 & 0.39 & 0.40 & 0.42 & 0.43 & 0.45 & 0.45 \\
\hline Jiangxi & 0.33 & 0.34 & 0.35 & 0.35 & 0.37 & 0.39 & 0.42 & 0.43 & 0.45 \\
\hline Shandong & 0.37 & 0.38 & 0.40 & 0.41 & 0.43 & 0.45 & 0.47 & 0.48 & 0.50 \\
\hline Henan & 0.29 & 0.30 & 0.31 & 0.32 & 0.37 & 0.40 & 0.42 & 0.43 & 0.45 \\
\hline Hubei & 0.38 & 0.37 & 0.37 & 0.38 & 0.41 & 0.43 & 0.44 & 0.47 & 0.48 \\
\hline Hunan & 0.40 & 0.38 & 0.39 & 0.40 & 0.42 & 0.44 & 0.46 & 0.49 & 0.52 \\
\hline Guangdong & 0.45 & 0.45 & 0.46 & 0.48 & 0.49 & 0.51 & 0.52 & 0.54 & 0.54 \\
\hline Guangxi & 0.35 & 0.34 & 0.35 & 0.36 & 0.38 & 0.39 & 0.40 & 0.44 & 0.45 \\
\hline Hainan & 0.46 & 0.46 & 0.47 & 0.48 & 0.52 & 0.53 & 0.54 & 0.56 & 0.57 \\
\hline Chongqing & 0.36 & 0.36 & 0.39 & 0.41 & 0.47 & 0.48 & 0.48 & 0.49 & 0.52 \\
\hline Sichuan & 0.35 & 0.33 & 0.35 & 0.35 & 0.39 & 0.44 & 0.47 & 0.50 & 0.51 \\
\hline Guizhou & 0.47 & 0.49 & 0.48 & 0.47 & 0.45 & 0.45 & 0.45 & 0.45 & 0.47 \\
\hline Yunnan & 0.40 & 0.42 & 0.41 & 0.42 & 0.43 & 0.45 & 0.47 & 0.48 & 0.47 \\
\hline Shaanxi & 0.36 & 0.35 & 0.35 & 0.35 & 0.37 & 0.41 & 0.42 & 0.42 & 0.43 \\
\hline Gansu & 0.37 & 0.39 & 0.40 & 0.41 & 0.44 & 0.49 & 0.51 & 0.54 & 0.55 \\
\hline Qinghai & 0.35 & 0.32 & 0.33 & 0.33 & 0.37 & 0.41 & 0.43 & 0.47 & 0.47 \\
\hline Ningxia & 0.42 & 0.41 & 0.42 & 0.42 & 0.43 & 0.44 & 0.45 & 0.47 & 0.48 \\
\hline Xinjiang & 0.32 & 0.36 & 0.36 & 0.37 & 0.41 & 0.45 & 0.45 & 0.46 & 0.46 \\
\hline
\end{tabular}

